火山島の自然環境変遷と，その人為との相互作用に関

するシステム科学的研究

一三宅島を中心として（第 3 年次）—

濱 田隆 士*

\title{
Environmental Changes and Their Relations to the Human Activities in Volcanic Isnalds: In the Case of 1983 Eruption of Miyake Volcano (The Third Year)
}

Takashi HAMADA

\section{I. まえがき}

当研究に対し, 東京地学協会より昭和 58,59 , $60 の 3$ 年度にわたって助成金が交付されたので, 本報告はその第 3 年次として，これまでの総括な らびに最近の進捗, 今後の展望を要約するもので ある。協同研究者一同, 協会に対し深い感謝の意 を表します。

\section{II. 研 究 経過}

研究開始時点において当面の目的とされたのは 近い過去に起こった昭和 15 , 同37年の 2 回の噴火 による地形や堆積物が，互いにどのように違った 過程を経て現在に至っているかを，火山プロパー の面のみならず，植物相や動物相の面からも捉 え, ひいては今後の噴火活動に備えるための知 識・情報を畜積することにあった。システム基礎 科学実習のフィールドとしてとり敢えず三宅島を 選定し，調査を開始した ${ }^{1}$ 矢先，昭和 58 年10月 3 日に，村営牧場の二男山に始まり延長 $4.5 \mathrm{~km}$ に
わたる山腹列状噴火が起こった 2),3)。

この緊急事態に即応して，調査項目を一部変 更・追加し，現場保存の困難な諸事象を可能な範 囲で情報収集することに力を注いだ。

i. 噴火とそれに伴う諸事象の詳細と時系列

ii. 火口列の形態と構成

iii. 各種昇華物

iv. 各部位の地熱

v. 動植物一の影響とその後の変遷

vi. 諸種応急対策事業

これらの調査結果の速報は「昭和57，58年度文部 省特定研究報告書」4) にまとめられた。上記各事 項の詳細は，いずれも長期計画に引継がれている が，それらのうちファイアカーテンへの吹き込み ガストや植生被害のタイプ分け等については，本 誌に記載・報告した ${ }^{5)}$ 。

\section{III. 植生遷移}

今回の噴火により，三宅島は昭和に大ってから 15，37，58と，3期の無生物期を現出し，22，21

* 東京大学教養学部基礎科学科第 2 (システム基礎科学), Department of Natural and Artificial Systems, University of Tokyo

1）濱田隆士 三宅島をテーマに一特定研と実習と一教養学部報，第 289 号，1983年 9 月 3 日（東京大 学教養学部)

2）濱田隆士 三宅島の噴火 学内広報, No. 615，1983年10月17日（東京大学広報委員会）

3）濱田隆士 三宅島その後 教養学部報，第291号，1983年12月 6 日 (東京大学教養学部)

4）濱田隆士編 (1984)：「火山島の自然環境変遷と, その人為との相互作用に関するシステム科学的研 究一昭和58年三宅島噴火活動を中心として」. 東大教養, 112頁，36カラー図版.

5）濱田隆士（1985）：三宅島一火山島システム総合研究のケース・スタディー. 地学雑誌 94 巻 1 号, 21-23頁. 
年の時閒差をもつ植生遷移が進行することになっ た。地勢・交通の便等を考慮すると，これほど好 条件の整った例は国の内外を通じて稀有のことで ある。

\section{0. 噴火直後の無生物域出現期}

1. 着生期 : スコリア・放出岩屑上にオレンジ 色のダイダイゴケ科の地衣類 Coloplaca sp. が認 められる。埋没樹幹の分解者としての変形菌類, きのこ類等が出はじめる。

2. 苔期 : 地衣類が消えた跡にはしばしばゼニ ゴケ, ヒョウタンゴケ等が着生し, 群落をつくり 始める。

3. 飛来種子発芽期 : スコリア・放出岩屑荒地 に飛来した八チジョウイタドリ，クロマツ，八チ ジョウイボタ，イヌホオズキ，アレチノギク等の 実生が認められる。

4. 定着期 : 発芽しても冬を越せないものが多 いなかで， 2 年目に入ると八チジョウイタドリや ヨモギ6)が群落拡大して定着植生となる。

$3^{\prime}$. 基幹発芽とその定着：降下スコリアや放 出岩片で著しく痛めつけられたスダジイ, タブノ キなどは，被苂後約 3 ケ月で早くも残った樹皮か ら基幹発芽し， 2 年目には安定して再生を確認で きたものが多い。なお，スギ，ヒノキ等の針葉樹 にはその力がなく立枯れたので，早期に伐採され た。

$3^{\prime \prime}$. 林床植生の置換 : 樹冠部を 失ない落葉が 著しかった森林では，イノデを除いて林床植生も ほとんどが滅び，春にはうって変って飛来種子か ら発芽した陽性の草本類が占め, 生き残った落葉 樹の芽吹きと共に明るい林床を形成した。しか し，この陽性林床も一過性であり，回生が進んで スダジイ, タブノキの樹冠が再形成され，フウト ウカズラが茂ってきた段階で，林床は再びイ， デ，チゴュリ，ライカカズラ， ウラシマソウ等の 卓越する陰性の植生によって置換されるものと思 われる。現在は枯れた樹冠の分散期にあり，林床
リッター層では落枝に対する分解者の作用が顕著 となっている。

なお，マグマ水蒸気爆発時の放出物によるボン ビングで傷ついた樹木のその後に関しては, 従来 継続観察の例がないので非常に注目に值する7。 2 年半を経たこの春には，主幹だけとなり，しか も途中から折れてしまったものでさえ，樹皮が生 きている場合は，その部分から基幹発芽したう え，樹皮の剝離側面を新樹皮が被うなど，本格的 な回生が認められる。

1977年の有珠山爆発時に調查された樹木㷋 害3)のうち, 降下火砕物粒径の大小による分類, a-1 (太枝・幹の折損), a-2（細枝の折損・強 制脱葉), $\mathrm{a}-3$ (モルタル状火山灰の付着, 屈折・屈 曲）というパターンは, 三宅島での例, とりわけマ グマ水蒸気爆発による噴出物での樹木被災パター ンにもよく適用できる。十分に水を含んだ降下物 は粘着性が大きく, 都会の春のドカ雪と同様の効 果を持ち，まさに黒い雪と呼べるものであった。

\section{IV. 動物相への影響}

a : 海浜生物一三宅島の海産物としてはテン グサとフクトコブシにかなりのウエイトがかかっ ているため, 噴火後, 東京都水産試験所大島分場 担当で，定期調査を実施している。昭和 37 年時に も同様調查が実施されており，今回との比較の結 果が期待されるが，噴火の部位と地勢・風向・沿 岸流等との関係が異なるので，詳細に関しては共 通性に欠けるところが出るかもしれない。

大局的にみると三宅島の海浜生物相は, 黒潮攻 撃面である西半と, その陰となって濁流のため湧 昇流の発生可能性が大きい東半とで違い, 前者が 造礁サンゴ群落, 後者がテングサ等の藻場, とい うコントラストを持つものとみられる。昭和 15, 37年の噴火は東北部を占めていたので, 降下堆積 物のプルームは海岸を幅狭く横切ったにとどまっ たのに対し，58年噴火では風上かつ上流側で起こ

6)一部のヨモギは，枯死林の林床緑化のため, 土地改良剤と共に空中散布されたものが含められてい る可能性が大きい.

7) 浜田隆士 (1984)：三宅島に緑よみがえる。科学朝日，9 月号，86-89頁.

8）岡村俊邦 (1985)：活火山地域における森林の成立過程に関する砂防学的研究. 地下資源調查所報 告第57号報文，29-69頁. 
り，プルームが海岸線にほぼ平行に伸びたため, 事情は大きく違っている。そのうえ, 最南部に夕 フリングが形成され，近くには海中流入溶岩もあ るので, 沿岸の水中火砕岩類は細片化しつつ移動 して, 浅海着生・座生生物相にかなりの被害を与 え, しかも長時間の後遺症がみられることになっ た。フクトコブシや八チジョウダカラの幼体一成 体混合大量死が顕著に認められる。しかし，1年 後には上流側で早くも自破研溶岩の破面上にコケ ムシや海藻，環虫類の着生と貝類等の付着が観察 され，回復は始まっており，“流砂”の流出ある いは定着が終れば，動植物相の復原は速いものと 推定される。

b：鳥類相一一全島バードサンクチュアリ化構 想が打出されたばかりの時期の噴火であり, しか も鳥が最も多く見られた新澪・大路両水域が被災 したので，鳥類相に大きな影響があったのではな いかと気遣われた。噴火後 1 年は確かにその周辺 の鳥類が著しく減少したものの, 緑の回復につれ て漸増してきた。噴火時が鳥相にとっては端境期 であったことや，周辺に代償森林があることなど から，被害は予想より少なかったと推定できる。

しかしながら, 大路池畔を営巣地としていたオ オミズナギドリにとっては極めて影響が大きく， クレーター壁の崩壊による土砂での埋立てとのダ ブルパンチに加え, 最近急激に増えているイタチ のために，観察されているだけでも月数羽の単位 で死んでいる。なお，イタチによる捕食は目下卜 カゲ類に集中しているようであるが，アカコッコ など地上生活型鳥類への影響は急速に増大寸る可 能性があると推定9)され，八丈島の蹾をふまぬた めの強力な対策が望まれる。

\section{V. 噴火後の研究傾向と社会情勢}

昭和58年三宅噴火に関する調查・研究は，発生
当初の応急対策的な経過について，文部省の自然 災害特別研究突発災害研究報告 10 亿一応のまとめ がなされている。しかし，噴火活動が鎮静化して からというものは，見学のために来島する研究者 や教師の数はふえたものの, 急速に減衰している とみて間違いない。例えば，日本火山学会での研 究発表では噴火後最初の1984年春季大会において 38/142件（分母は講演総数）もあり，機関誌「火 山」 29 巻 2 号は三宅島噴火特集号となった。しか るに，同年秋季には $9 / 67$ 件， 1985年春季には $1 /$ 103件となってしまって预り，その 1 件も本研究 グループメンバーによるものであるから，講演数 でみる限り，他には継続する火山学研究がなくな ってしまった感すらするのである。噴火現象が一 過性であるための特別な事情かもしれないが，大 局的にみて火山と長期に総合的に取組む姿勢がい かにそしいかがわかる。日本は火山国であり，材 料に不足はないので, 不測の事態を念頭に入れ, 各大学に担当火山を割振り, 火山学的側面のみな らず，総合プロジェクトとして継続研究を計るな らば，必ずや次の緊急事態発生時に役立つ結果が もたらされるであろう。

噴火直後に起こった “官民共用空港” 問題は, 火山島に密着して生きてきた島民の社会・意識シ ステムと, 国家優先の政治姿勢, それに基地公害 問題とが絡んで複雑な様相を呈している。島民感 情の十分な検討がないままに先行した手続上の不 備むさることながら，国策レベルの要請と民意尊 重の民主政治との狭間にあって，目下双方にとり 何の利もない情況となっている。自然保護や火山 研究の場としての発言も㐫り, 火山島と極度の人 為システムとの相互作用の研究上, 注視しつゔけ たい11。

9）バードアイランド三宅島に危機：科学朝日，1985年 1月号，62-63頁 (TOPICS).

10）下鶴大輔 (1984編)：自然災害特別研究突発災害研究成果報告書，1-290頁.

11）浜田隆士（1984）：1983年三宅島噴火の前後事情，UP，13巻 8 号，18-22頁，東京大学出版会. 